\title{
Pemanfaatan Kulit Buah Naga Merah (Hylocereus polyrhizus) sebagai Pewarna Alami Kosmetik Pemerah Pipi (Blush On)
}

\author{
Utilization of Red Dragon Fruit (Hylocereus polyrhizus) as A Cosmetic \\ Natural Dye of Blush On
}

\author{
Febri Rizki Ramadani ${ }^{1}$, Saisa $^{* 2}$, Ria Ceriana ${ }^{3}$, Thursina Andayani ${ }^{4}$ \\ ${ }^{1,3,4}$ Program Studi Farmasi, Fakultas Ilmu Kesehatan, Universitas Ubudiyah Indonesia, Banda Aceh, Indonesia \\ ${ }^{2}$ Program Studi Teknik Kimia, Fakultas Teknik, Universitas Serambi Mekkah, Banda Aceh, Indonesia
}

*Korespondensi Penulis: saisa@serambimekkah.ac.id

\begin{abstract}
Abstrak
Kulit dari buah naga merah merupakan limbah yang jarang dimanfaatkan. Kebanyakan hanya dibuang tanpa diolah menjadi bahan yang memiliki manfaat, sehingga perlu adanya alternatif untuk memanfaatkan kulit buah naga. Pemanfaatan yang dapat dilakukan adalah dengan mengekstraknya sehingga akan diperoleh ekstrak yang dapat dimanfaatkan sebagai pewarna makanan, kosmetik, dan tekstil. Tujuan penelitian ini untuk memanfaatkan limbah kulit buah naga sebagai pewarna alami kosmetik pemerah pipi. Ekstrak diperoleh dengan cara maserasi menggunakan pelarut etanol 96\%, formulasi pewarna pipi yang dibuat yaitu menggunakan zat warna dari ekstrak kulit buah naga dengan kosentrasi $15 \%, 20 \%$, 25\% dengan bahan talkum, zink oksida, kaolin dan nipagin. Pengujian yang dilakukan antara lain: uji stabilitas, uji pH, uji keretakan dan uji kesukaan. Formulasi dengan konsentrasi 15 \%, 20\%, dan 25\% masing-masing dari sediaan mengalami perubahan warna pada hari kedua. semua sediaan tidak retak dijatuhkan pada ketinggian $8-10 \mathrm{~cm}$. $\mathrm{pH}$ dari setiap sediaan stabil, formula dengan konsentrasi $15 \%$ memiliki pH 7, $20 \%$ 6, dan $25 \% 6$.
\end{abstract}

Kata Kunci: ekstrak kulit Hylocerus polyrhizus, kosmetik, pemerah pipi

\begin{abstract}
The peel of red dragon fruit is a rarely used waste. Most are only disposed without being processed into materials that have benefits. The skin of the dragon fruit contains high enough antioxidants, so there is an alternative to take advantage of dragon fruit skin. Utilization that can be done is to extract it so that will be obtained extract that can be used as food coloring, cosmetics, and textile. The purpose of this study is to utilize dragon fruit skin waste as a natural dye cosmetic rouge.The extract was obtained by maceration using $96 \%$ ethanol solvent, a cheese dye formulation was made using dyes from dragon fruit skin extract with $15 \%$ concentration, 20\%, 25\% with talc, zinc oxide, kaolin and nipagin. Tests performed include: stability test, $p H$ test, crack test and favorite test.The formulations with concentrations of 15\%,20\%, and 25\% of each of the preparations undergo a discoloration on the second day. all non-cracked preparations were dropped at an altitude of $8-10 \mathrm{~cm}$. $\mathrm{pH}$ of each stable preparation, the formula with a concentration of 15\% has a pH of 7, 20\% 6, and $25 \% 6$.
\end{abstract}

Keywords: Hylocerus polyrhizus peel extract, cosmetic, blush on 


\section{PENDAHULUAN}

Kulit dari buah naga merah merupakan limbah yang jarang dimanfaatkan. Kulit dari buah naga mengandung antioksidan yang cukup tinggi, sehingga perlu adanya alternatif untuk memanfaatkan kulit buah naga. Pemanfaatan yang dapat dilakukan adalah dengan mengekstrak sehingga akan diperoleh ekstrak yang dapat dimanfaatkan sebagai pewarna makanan, kosmetik, dan tekstil. Berdasarkan beberapa penelitian menyebutkan kandungan kulit buah naga yaitu flavonoid, vitamin A, C, E dan polifenol (Handayani, 2014). Hal ini juga didukung dengan penelitian Noor, (2016), bahwa ekstrak kulit buah naga merah memiliki kandungan berupa vitamin $\mathrm{C}$, flavonoid, tanin, alkaloid, steroid, dan antosianin. Antosianin merupakan zat warna yang berperan memberikan warna merah, dapat dijadikan alternatif pengganti pewarna sintesis, yang baik digunakan untuk pewarna alami kosmetik (Handayani, 2012).

Kosmetik merupakan produk yang dipakai berulang-ulang setiap hari, mulai dari rambut sampai ke ujung kaki. Tujuan menggunakan kosmetik ini adalah untuk meningkatkan kepercayaan diri. Saat ini kosmetik merupakan suatu kebutuhan yang sangat diperlukan, terutama pada wanita, akan tetapi produk-produk kosmetik yang beredar di pasaran saat ini hampir seluruhnya menggunakan bahan pewarna sintesis seperti rhodamin B. Hasil temuan Badan Pengawas Obat dan Makanan (BPOM) Departemen Kesehatan RI mengumumkan pada hari kamis (27/12/2012) di Jakarta, ditemukan 48 jenis produk kosmetik mengandung zat berbahaya, salah satu zat yang berbahaya adalah rhodamin B. Penelitian dari beberapa jenis kosmetik tersebut dilakukan dari bulan Januari hingga Oktober 2012, dari ke 48 jenis produk kosmetik tersebut beberapa produk dinyatakan positif mengandung rhodamin $\mathrm{B}$ (BPOM, 2012).

Rhodamin B adalah bahan pewarna yang berbahaya, yang umumnya dibuat sebagai pewarna tekstil. Rhodamin B bersifat karsinogenik sehingga dalam penggunaan jangka panjang dapat menyebabkan kanker, efek negatif lainnya dapat menyebkan gangguan fungsi hati bahkan bisa menyebabkan kanker hati (Anonim, 2008).

\section{METODE PENELITIAN}

\section{Alat dan Bahan}

Alat yang digunakan dalam pembuatan blush on, adalah: Pisau, wadah maserasi, penyaring kain, kertas saring,blender, timbangan, spatula, wadah blush on, gelas ukur, pipet, 
rotary vacum evaporator, kertas $\mathrm{pH}$, pipet tetes, mortal. Bahan yang akan digunakan dalam penelitian ini adalah: Kulit buah naga 200 gram, etanol 96\% 400 ml, talkum 100 gr, kaolin 40 gr, zink oksida 30 gr, nipagin 3 gr.

\section{Prosedur Kerja}

\section{Proses Ekstrak Kulit Buah naga}

Terlebih dahulu kulit buah naga dipisahkan dari dagingnya, kemudian dibersihkan lalu di potong kecil-kecil. Ekstraksi menggunakan pelarut etanol 96\%, dengan metode maserasi dengan perbandigan 1:3 selama 1 hari. Bahan-bahan yang sudah disiapkan yaitu kulit buah naga dan etanol dicampur atau diletakkan di dalam sebuah wadah maserasi, etanol harus bisa merendam semua kulit buah naga. Bahan yang berada di dalam wadah direndam selama 24 jam, untuk mendapatkan tekstur lebih halus, kemudian hasilnya disaring menggunakan penyaring kain yang tidak begitu rapat, penyaringan dilakukan 3 kali menggunakan penyaring kain. Penyaringan ke 4 menggunakan penyaring kertas yang lebih rapat guna mendapatkan tingkat kejernihannya. Tahap selanjutnya hasil ekstraksi kemudian dipekatkan menggunakanrotary vacum evaporator untuk mendapatkan hasil ekstrak murni (Prasetyo, 2015).

\section{Uji Fitokimia}

a. Uji Flavonoid

Satu gram sampel dimasukkan dalam labu erlenmeyer dan ditambah etanol 25 mL. Kemudian dipanaskan sampai mendidih dan disaring. Filtrat yang diperoleh diuapkan sampai volume pelarut tinggal setengahnya. Filtrat dibagi menjadi dua, tabung pertama blanko dan tabung kedua ditambah beberapa tetes etanol, dikocok kemudian ditambahkan serbuk magnesium dan teteskan $5 \mathrm{M}$ asam klorida. Bila timbul warna merah maka ekstrak mengandung flavonoid (Harbone, 1987).

b. Uji Tanin

Sampel sebanyak 2 gram dihaluskan dan ditambahkan metanol dan di saring. Filtratnya ditambahkan $\mathrm{NaCl}$ 10\% dan disaring. Filtrat dibagi menjadi 2 bagian. Masing-masing ditetesi dengan gelatin $10 \%$ dan $\mathrm{FeCl} 3$ 10\%. Jika ada endapan menunjukkan positif tanin sebaliknya jika tidak ada endapan menunjukkan negatif (Harbone, 1987). 


\section{c. Uji Alkaloid}

Sebanyak $2 \mathrm{~mL}$ ekstrak ditambah 2,5 mL amoniak dan 2,5 $\mathrm{mL}$ kloroform. Larutan disaring kedalam tabung reaksi, dan filtrat ditambahkan asam sulfat $2 \mathrm{~N}$ sebanyak 10 tetes. Filtrat dikocok dengan teratur kemudian dibiarkan beberapa lama sampai terbentuk dua lapisan. Lapisan atas pindahkan kedalam tiga tabung reaksi, kemudian larutan dianalisis dengan pereaksi Mayer, Dragendrof dan Bouchardat Terbentuknya endapan menunjukkan adanya kandungan alkaloid. Reaksi dengan pereaksi Mayer akan terbentuk endapan putih, dengan pereaksi Dragendroff terbentuk endapan merah jingga dan dengan perekasi Bouchardat terbentuk endapan coklat (Harbone, 1987).

d. Uji Terpenoid

Uji terpenoid dilakukan dengan terlebih dahulu menyiapkan $2 \mathrm{ml}$ ekstrak yang telah dilarutkan dalam pelarutnya. Larutan tersebut kemudian diuapkan di dalam caan porselen. Residu dilarutkan dengan $0,5 \mathrm{ml}$ kloroform dan ditambahkan 0,5 asam asetat pekat anhidrad. Asam sulfat pekat sebanyak $2 \mathrm{ml}$ ditambahkan melalui dinding tabung reaksi. Reaksi positif terpenoid ditunjukkan dengan terbentuknya cincin kecoklatan atau violet pada perbatasan larutan (Harbone, 1987).

e. Uji Saponin

Uji saponin dilakukan ekstrak sampel sebanyak 1 gram dimasukkan ke dalam tabung reaksi, kemudian ditambahkan akuades hingga seluruh sampel terendam, dididihkan selama 2-3 menit, dan selanjutnya didinginkan kemudian dikocok. Hasil positif ditunjukkan dengan terbentuknya busa yang stabil. (Minarno, 2015).

f. Uji Steroid

Sebanyak $2 \mathrm{~mL}$ sampel ditambah dengan pereaksi Liberman-Burchard $1 \mathrm{~mL}$. Adanya streoid ditunjukkan dengan terbentuknya warna biru atau hijau kehitaman(Harbone, 1987). 


\section{Membuat formula dalam pembuatan blush on Compact meliputi:}

Tabel 1. Rancangan formulasi blush on

\begin{tabular}{|l|c|c|}
\hline \multicolumn{1}{|c|}{ Bahan } & $\begin{array}{c}\text { Formulasi } \\
\text { dasar }\end{array}$ & $\begin{array}{c}\text { Formulasi Blush on } \\
\text { Ekstrak Kulit Buah } \\
\text { Naga }\end{array}$ \\
\hline Ekstrak Kulit Buah naga & - & 60 gram \\
\hline Talcum & 80 gram & 80 gram \\
\hline Kaolin & 40 gram & 40 gram \\
\hline Nipagin & 2 gr & 2 gr \\
\hline Zink oksida & 30 gram & 30 gram \\
\hline
\end{tabular}

Pembuatan pemerah pipi (blush on) dalam bentuk padat menurut (Nurhayati, 2016)

a. Menyiapkan dan penimbangan bahan meliputi: 60 gram ekstrak buah naga, talkum 80 gr, kaolin 40 gr, nipagin 2 gr, zink oksida 30 gr

b. Bahan seperti zink oksida, kaolin, nipagin digerus dalam lumpang sampai tekstur menjadi lebih halus.

c. Campurkan ekstrak kulit buah naga gerus sampai warna merata

d. Masukkan talkum sedikit demi sedikit, aduk sediaan sampai warna tercampur rata

e. Kemudian, bahan yang sudah tercampur rata diletakkan pada wadah yang sudah disediakan

f. Selanjutnya, bahan yang sudah diletakkan pada wadah di keringkan dengan suhu kamar sampai bahan benar- benar kering.

\section{Evaluasi sediaan pemerah pipi (blush on)}

Evaluasi / pengujian mutu sediaan meliputi:

a. Uji Stabilitas

Uji ini meliputi parameter organoleptik yaitu dilakukan pengamatan terhadap adanya perubahan bentuk, warna, dan bau dari sediaan pewarna pipi dilakukan terhadap masing-masing sediaan selama penyimpanan pada suhu kamar pada hari ke1, hari ke-7, hari ke-15 dan selanjutnya setiap 5 hari sekali hingga hari ke-90 (Anvisa, 2005).

b. Uji keretakan

Sediaan dijatuhkan pada permukaan kayu beberapa kali pada ketinggian 8-10 inci. Diamati bentuknya, sediaan yang tidak pecah dinyatakan memenuhi syarat. 
c. Uji pH

Pengukuran $\mathrm{pH}$ dilakukan dengan menggunakan kertas $\mathrm{pH}$. pengukuran $\mathrm{pH}$ pada sediaan pemerah pipi (blush on) digunakan untuk mengetahui cocok atau tidak pemerah pipi yang dibuat pada penelitian ini apabila diaplikasikan pada kulit. Syarat $\mathrm{pH}$ sediaan pemerah pipi yang baik sesuai dengan interval $\mathrm{pH}$ kulit secara umum yaitu $4-7$.

d. Uji Kesukaan

Uji kesukaan ini dilakukan untuk mengetahui tingkat kesukaan panelis terhadap sediaan yang dibuat. Jumlah panel uji kesukaaan makin besar semakin baik. Pada penelitian ini jumlah responden sebanyak 10 orang. Setiap responden memberikan penilaian terhadap masing-masing pewarna pipi berdasarkan tekstur/bentuk, dan aromanya.

\section{HASIL DAN PEMBAHASAN}

\section{Hasil Ekstraksi Kulit Buah Naga}

Hasil maserasi dari 200 gram kulit buah naga diperoleh $400 \mathrm{ml}$ maserat, pada penelitian ini maserasi dilakukan dengan menggunakan pelarut etanol 96\%, pelarut ini dipilih karena lebih murni dan antosianin lebih stabil jika pelarutnya yang digunakan etanol 96\% (Wijaya, dkk 2001). Setelah proses maserasi kemudian maserat dipekatkan dengan rotary evaporator dengan suhu $55{ }^{\circ} \mathrm{C}$, karena dengan suhu $55^{\circ} \mathrm{C}$ zat aktif tidak mudah rusak dan tetap stabil, jika suhu terlalu tinggi zat aktif bisa rusak. Maserat yang dipekatkan menghasilkan 72 gram estrak kental. Rendemen yang diperoleh yaitu $36 \%$.

\section{Hasil Uji Fitokimia}

Pengujian fitokimia ini dilakukan untuk mengetahui keberadaan golongan senyawa metabolit skunder yang ada dalam ekstrak kulit buah naga merah (Hylocereus polyrhizus). Pada penelitian ini dilakukan pengujian adanya senyawa golongan alkaloid, terpenoid, saponin, flavonoid dan fenolik/tanin. Hasil pengujian ekstrak kulit buah naga dapat dilihat pada tabel 2 . 
Tabel 2. Hasil pengujian Fitokimia ekstrak kulit buah naga

\begin{tabular}{|l|l|c|}
\hline Golongan & Reagen & Hasil \\
\hline \multirow{3}{*}{ Alkaloid } & Mayer & - \\
\cline { 2 - 3 } & Weagner & + \\
\cline { 2 - 3 } & Dragendorff & + \\
\hline Flvonoid & $0,5 \mathrm{Mg}$ dan Hcl & + \\
\hline Saponin & Pengocokan & + \\
\hline Fenolik/tanin & $\mathrm{FeCl}_{3}$ & + \\
\hline Steroid & Uji Liebermann-Burchard & - \\
\hline Terpenoid & Uji Liebermann-Burchard & - \\
\hline
\end{tabular}

Keterangan: + (ada) - (tidak ada)

Hasil uji fitokimia menunjukkan bahwa ekstrak kulit buah naga merah (Hylocereus polyrhizus), mengandung senyawa alkaloid. Uji alkaloid pada penelitian ini menggunakan tiga reagen yaitu mayer, weagner dan dragendorf. Ada atau tidaknya senyawa alkaloid dalam eksrak biasa dilihat dari hasil pengamatan, pada reagen mayer ditandai dengan terbentuknya endapan putih, pada reagen weagner ditandai dengan terbentuknya endapat coklat, dan pada reagen dragendorff terdapat endapan merah. Hasil pengamatan pada penelitian ini dari keriga reagen, hanya reagen mayer yang menunjukkan nilai negatif (-), jadi dapat disumpulkan eksrak kulit buah naga mengandung senyawa alkaloid.

Hasil uji juga menunjukkan adanya flavonoid, yang ditandai terbentuknya endapan orange pada reagen, reagen uji flavonoid ialah $0,5 \mathrm{Mg}$ dan $\mathrm{HCl}$. pengujian saponin dengan cara pengocokan ekstrak yang telah dicampur dengan aquades, hasil pengamatan menunnjukkan positif adanya saponin dalam eksrak karena terdapat busa pada reagen. Uji fenolik/tanin dengan menggunakan reagen $\mathrm{FeCl}_{3}$, hasil pengamatan menunjukkan positif adanya fenolik/tanin dalam ekstrak kulit buah naga karena terdapat endapan hijau pada reagen.

Uji steroid dilakukan dengan uji Liebermann-Burchard, dari hasil pengamatan, ekstrak kulit buah naga tidak mengandung steroid, karena tidak terdapat warna hijau pada reagen. Uji terpenoid juga menggunakan uji Liebermann-Burchard, hasil pengamatan menunnjukkan ekstrak kulit buah naga tidak mengandung terpenoid karena tidak ada endapan ungu pada reagen. 


\section{Hasil Formulasi Pemerah Pipi (Blush on)}

Dalam penelitian ini dilakukan formulasi dengan variasi konsentrasi ekstrak kulit buah naga sehingga menghasilkan perbedaan intensitas warna pewarna pipi. Sediaan dengan konsentrasi 15\% menghasilkan warna merah jambu muda, konsentrasi $20 \%$ menghasilkan warna merah jambu, dan konsentrasi $25 \%$ menghasilkan warna merah jambu tua. Perbedaan intensitas warna dari ketiga formulasi pemerah pipi (blush on) dipengaruhi oleh penambahan konsentrasi pigmen ekstrak kulit buah naga pada formulasi, semakin tinggi kosentrasi maka semakin pekat warna sediaan.

\section{Hasil Uji Stabilitas}

Uji stabilitas dilakukan untuk mengetahui keefektifan warna, aroma dan bentuk dari sediaan selama penyimpanan. Hasil uji stabilitas dapat dilihat pada Tabel 3.

Tabel 3. Hasil Uji stabilitas

\begin{tabular}{|l|l|l|l|}
\hline Pengamatan & \multirow{2}{*}{ Sediaan } & Lama pengamatan (Hari) \\
\cline { 3 - 4 } & & 1 & 7 \\
\hline \multirow{5}{*}{ Bentuk } & $\mathrm{A}($ Basis) & Baik & Baik \\
\cline { 2 - 4 } & $\mathrm{B}(15 \%)$ & Baik & Baik \\
\cline { 2 - 4 } & $\mathrm{C}(20 \%)$ & Baik & Baik \\
\cline { 2 - 4 } & $\mathrm{D}(25 \%)$ & Baik & Baik \\
\hline \multirow{5}{*}{ Warna } & $\mathrm{A}($ Basis) & Putih & Putih \\
\cline { 2 - 4 } & $\mathrm{B}(15 \%)$ & Merah jambu muda & Coklat muda \\
\cline { 2 - 4 } & $\mathrm{C}(20 \%)$ & Merah jambu & Coklat tua \\
\cline { 2 - 4 } & $\mathrm{D}(25 \%)$ & Merah jambu tua & Coklat tua \\
\hline \multirow{5}{*}{ Aroma } & $\mathrm{A}($ Basis) & Aroma khas & Aroma khas \\
\cline { 2 - 4 } & $\mathrm{B}(15 \%)$ & Aroma khas & Aroma khas \\
\cline { 2 - 4 } & $\mathrm{C}(20 \%)$ & Aroma khas & Aroma khas \\
\cline { 2 - 4 } & $\mathrm{D}(25 \%)$ & Aroma khas & Aroma khas \\
\hline
\end{tabular}

Hasil uji stabilitas warna sediaan pewarna pipi (blush on) dengan penambahan pigmen ekstrak kulit buah naga tidak stabil selama penyimpanan.Perubahan warna sediaan pada hari kedua penyimpanan warna sudah mulai berubah.Hasil pengamatan bisa dilihat pada tabel, semakin tinggi konsentrasi warna sediaan, dengan bertambahnya hari semakin gelap warna sediaan. Hal ini terjadi karena antosianin sangat mudah teroksidasi oleh cahaya sehingga warna menjadi tidak stabil. Seperti yang dijelaskan oleh ara (2014) pada penelitiannya selain cahaya suhu, kelembapan, dan $\mathrm{pH}$ juga mempengaruhi kestabilan antosianin. Antosianin stabil pada pH 3,5 (Fennema, 1996). Dari hasil pengamatan bentuk (tekstur) dari ke empat sediaan pemerah pipi (blush on) yang dibuat tetap stabil selama penyimpanan. 
Hasil pengamatan aroma dari semua sediaan memiliki aroma khas, selama penyimpanan aroma pada masing-masing sediaan tidak terjadi perubahan aroma, jadi dapat disimpulkan bahwa aroma dari keempat sediaan yang dibuat stabil selama penyimpanan.

\section{Hasil Uji Keretakan}

Hasil pemeriksaan yang didapat terhadap semua sediaan pewarna pipi dengan uji keretakan menunjukan bahwa semua sediaan yang dibuat tidak pecah dan retak pada saat dijatuhkan pada permukaan kayu dengan ketinggian 8-10 (inci). Hasil uji keretakan dapat dilihat pada Tabel 4 berikut ini:

Tabel 4. Hasil Uji Keretakan

\begin{tabular}{|l|l|l|l|}
\hline \multirow{2}{*}{ Sediaan } & \multicolumn{3}{|l|}{ Dijatuhkan pada permukaan kayu pada ketinggian 8-10 (inci) 3 kali } \\
\cline { 2 - 4 } & Perlakuan 1 & Perlakuan 2 & Perlakuan 3 \\
\hline Basis & Tidak pecah & Tidak pecah & Tidak pecah \\
\hline $15 \%$ & Tidak pecah & Tidak pecah & Tidak pecah \\
\hline $20 \%$ & Tidak pecah & Tidak pecah & Tidak pecah \\
\hline $25 \%$ & Tidak pecah & Tidak pecah & Tidak pecah \\
\hline
\end{tabular}

Hasil pemeriksaan yang didapat terhadap sediaan pewarna pipi (blush on) dengan uji keretakan menunjukkan bahwa semua sediaan yang dibuat tidak pecah. Menurut Butler (2000), jika sediaan yang dihasilkan tidak rusak, mengindikasikan bahwa kekompakannya lulus uji. Maka semua sediaan yang dibuat memenuhi persyaratan uji keretakan.

\section{Hasil Uji pH}

Berdasarkan pengujian $\mathrm{pH}$ yang dilakuakan terhadap sediaan pemerah pipi tanpa penambahan ekstrak kulit buah naga memiliki $\mathrm{pH}$ 7, sedangkan $\mathrm{pH}$ ekstrak kulit buah naga yaitu 5. Formulasi dengan konsentrasi $15 \%$ memiliki $\mathrm{pH} 7$, formulasi dengan konsentarsi $20 \%$ memiliki pH 6, formulasi dengan konsentrasi 25\% memiliki pH 6. Berdasarkan hasil penelitian pengukuran $\mathrm{pH}$ terhadap masing-masing sediaan pemerah pipi (bluh on) dapat dilihat pada tabel 5 . 
Tabel 5. Hasil Uji pH

\begin{tabular}{|l|c|}
\hline \multicolumn{1}{|c|}{ Sediaan } & pH \\
\hline Basis & 7 \\
\hline Formulasi 15\% & 7 \\
\hline Formulasi 20\% & 6 \\
\hline Formulasi 25\% & 6 \\
\hline
\end{tabular}

Berdasarkan hasil pengamatan yang dilakukan nilai $\mathrm{pH}$ formulasi tanpa penambahan ekstrak kulit buah naga memiliki pH netral 7 hampir mendekati basa (tidak memenuhi syarat) sedangkan ekstrak kulit buah naga bersifat asam dengan pH 5. Dengan demikian dapat disimpulkan bahwa dengan penambahan ekstrak kulit bauh naga dengan konsentrasi 15\%, 20\%, dan $25 \%$ cocok diaplikasikan pada sediaan pemerah pipi (blush on).

\section{KESIMPULAN}

Berdasarkan hasil penelitian ini dapat disimpulkan bahwa, dalam ekstrak kulit buah naga merah (Hylocereus polyrhizus) terdapat antosianin/pigmen, namun tidak efektif dijadikan sebagai pewarna alami untuk formulasi pemerah pipi (blus on). Ekstrak kulit buah naga tidak dapat dijadikan sebagai alternatif pengganti pewarna sintesis pada kosmetik pemerah pipi (blush on), karena warna tidak stabil setelah diaplikasikan pada masing-masing sediaan, warna mulai memudar dihari kedua bahkan menjadi kecoklatan mulai hari ke 3. Dari hasil penelitian kulit buah naga dapat diekstrak sehingga menghasilkan ekstrak kental berwarna merah tua sebanyak 72 gram dan memperoleh rendemen $36 \%$.

\section{SARAN}

Disarankan untuk dilakukan penelitian selanjutnya meneliti bagaimana cara mencegah ketidakstabilan sediaan pewarna pipi menggunakan ekstrak kulit buahh naga sebagai pewarna alami. 


\section{DAFTAR PUSTAKA}

Anvisa. (2005). Cosmetic Products Stability Guide, Edisi Kesatu. Brasilia: National Health Survailance Agency Press.

Ara, I. (2014). Formulasi Sediaan Pewarna Pipi Menggunakan Ekstrak Bunga Kecombrang (Etlingera elatior Jack) Sebagai Pewarna, skripsi, Program Studi Sarjana Farmasi, Fakultas Farmasi, Universitas Sumatera Utara. Medan

Badan Pengawas Obat dan Makanan Republik Indonesia, (2012)

Butler H. (2000). Poucher's Perfumes, Cosmetics, and Soaps. Edisi ke-10. London: Kluwer Academic Publisher. Hal. 188-189.

Fennema, O.R. (1996). Food Chemistry.Edisi Ketiga. New York: Marcel Dekker Inc. Hal. 320-325

Handayani, P, A., Rahmawati, A.(2012). Pemanfaatan Kulit Buah Naga (Dragon Fruit) Sebagai Pewarna Alami Makanan Pengganti Pewarna Sintetis, Jurnal Bahan Alam Terbarukan, Program Studi Teknik Kimia, Fakultas Teknik, Universitas Negeri Semarang, Semarang

Handayani, S. (2014). Kandungan Kimia Beberapa Tanaman Dan Kulit Buah Berwarna Serta Manfaatnya Bagi Kesehatan. Jurnal, Fakultas Matematika dan Ilmu Pengetahuan Alam, Universitas Negeri Yogyakarta, Yogyakarta

Harborne, J B. (1987). Metode Fitokimia. Bandung : Penerbit ITB

Prasetyo, S., dan Yosephia, F. (2012). Model Perpindahan Massa Pada Ekstraksi Saponin Biji Teh Dengan Pelarut Isopropil Alkhohol 50\% Dengan Pengontakan Secara Dispersi Menggunakan Analisis Dimensi, Jurnal, Jurusan Teknik Kimia Universitas Katolik Parahyangan , Bandung.

Wijaya, S.L.,Widjanarko, B.S.,dan Susanto, T. (2001).Ekstraksi danKarakterisasi Pigmen dari Kulit Buah Rambutan (Nephelium lappaceum L)var. Binjai.Jurnal Biosain. 